\title{
Upper Cretaceous intertrappean non-marine Ostracoda from Mohagaonkala (Mohgaon-Kalan), Chhindwara District, Madhya Pradesh State, Central India
}

\author{
ROBIN WHATLEY ${ }^{1}$, SUNIL BAJPAI ${ }^{2} \&$ S. SRINIVASAN ${ }^{3}$ \\ ${ }^{1}$ Micropalaeontology Research, Department of Geology, Institute of Earth Sciences, University of Wales, Aberystwyth SY23 3DB, UK \\ (e-mail: riw@aber.ac.uk) \\ ${ }^{2}$ Department of Earth Sciences, University of Roorkee, Roorkee, India (e-mail: sunilfes@rurkiu.ernet.in) \\ ${ }^{3} 97 / \mathrm{C} / \mathrm{G} / 5$, Teachers' Colony, 2nd Street, Tuticorn 628 008, Tamil Nadu, India
}

\begin{abstract}
A rather impoverished fauna of only nine species of non-marine Ostracoda, belonging to seven genera was recovered from the classic intertrappean locality of Mohagaonkala (Mohgaon-Kalan), in Central India. Two species are cytherids and the remainder cyprids. Three of the species are new: Gomphocythere paucisulcata sp. nov., Cypridopsis elachistos sp. nov. and Zonocypris labyrinthicus sp. nov., while the remaining six species have been described previously from a variety of Upper Cretaceous localities in Peninsular India. Although one species Frambocythere tumiensis (Helmdach) occurs outside India, the sub-species which occurs at this locality, F. t. lakshmiae Whatley \& Bajpai, is an Indian endemic. The present fauna confirms that the non-marine Ostracoda of the intertrappeans are essentially endemic to India, despite prior claims to the contrary. J. Micropalaeontol. 21(2): 105-114, December 2002.
\end{abstract}

\section{INTRODUCTION}

In Peninsular India, the sedimentary intercalations ('intertrappean beds') occurring within the Deccan volcanics have long been known to yield non-marine microfossil assemblages, although in the south and east of the volcanic province, marine intercalations are encountered. In recent years, there has been a revival of interest in the intertrappean biotas because of their importance in constraining the age and correlation of the Deccan basalts in different individual parts of the volcanic province. Additionally, from a geodynamic standpoint, these fossils have provided significant insights into the question of the palaeobiogeographical relations of India with surrounding landmasses around the time of the K/T boundary (Jaeger et al., 1989; Sahni \& Bajpai, 1991; Prasad \& Rage, 1991; Whatley \& Bajpai, 2000c).

\section{The locality}

A rather limited fauna of nine species of Ostracoda, belonging to seven genera, was collected from the classical intertrappean locality at Mohagaonkala (Mohgaon-Kalan), (Lat. $79^{\circ} 11^{\prime} \mathrm{E}$; Long. $22^{\circ} 1^{\prime} \mathrm{N}$ ), in Chhindwara District, in the central Indian state of Madhya Pradesh. The locality is particularly well known for its plant megafossils (Sahni \& Rode, 1937; Bande et al., 1988) on the basis of which a Tertiary age was traditionally given to these intertrappean deposits. However, recent palynological investigations (Kar \& Srinivasan, 1998) have revealed the presence of a number of Maastrichtian species, including Aquilapollenites bengalensis and Gabonisporites vigourouxii at this locality.

The samples on which this study is based were collected by one of us (S. S.) from a spoil heap produced by the digging of an unlined well, located some $0.5 \mathrm{~km}$ west of Mohagaonkala. The intertrappean deposit is approximately $0.75 \mathrm{~m}$ thick and is sandwiched between two lava flows. The ostracod-bearing bed is a $0.25 \mathrm{~m}$ thick deposit of carbonaceous shale from near the top of the intertrappean deposit. The ostracods occurred in association with a large number of dinosaur eggshell fragments (Srinivasan, 1996) as well a number of spores and pollen grains
(Kar \& Srinivasan, 1998). Additional samples from a somewhat similar section at Dongargaon (Fig. 1), some $200 \mathrm{~km}$ to the south, failed to yield an ostracod fauna.

\section{The Ostracoda}

Sowerby (1840) and Jones (1860) first reported Ostracoda from the intertrappean beds. Following these pioneering studies, Bhatia and co-workers (Bhatia \& Rana, 1984; Bhatia et al., 1990a, b, 1996) described the ostracods from a number of localities (Nagpur, Asifabad, Kota) and discussed their age and biogeographical affinities. In another study, Mathur \& Verma (1988) described a fauna from the intertrappean beds of Rajasthan. Singh (1995 MS) and Singh \& Sahni (1996), discussed the age and faunal affinities of the Bombay intertrappeans based on a variety of fossil groups, with special attention being given to the Ostracoda, while Udhoji \& Mohabey (1996) considered the Ostracoda in their study of the age and palaeozoogeographical implications of the late Cretaceous Lameta Formation of Maharashtra. Sahni \& Khosla (1994) and Khosla \& Sahni (2000) reported the occurrence of Ostracoda in the Lameta Formation of Jabalpur Cantonment, in Madhya State. Bhandari \& Colin (1999) described an important fauna from Anjar, Kachchh.

This is the fifth in a series of papers that describe non-marine late Cretaceous Ostracoda from intertrappean horizons in the Deccan Traps. Previously we have described the faunas from three localities in Kaachchh (Kutch), in the state of Gujarat; from Lakshmipur (Whatley \& Bajpai, 2000a), Anjar (Whatley \& Bajpai, 2000b), and Kora (Bajpai \& Whatley, 2001). Another fauna, with several new taxa, has been described from two localities, Chandarki and Yanagundi in Gulbarga District, Karnataka State (Whatley et al., 2002). Many of the ostracod species encountered in these studies had not been described previously, while others were previously incorrectly assigned to contemporary species described from Mongolia and China. Whatley \& Bajpai (2000c) have shown that the Indian late Cretaceous intertrappean ostracods do not, as previously stated by many authors, indicate close Asian affinities. Rather, at the 


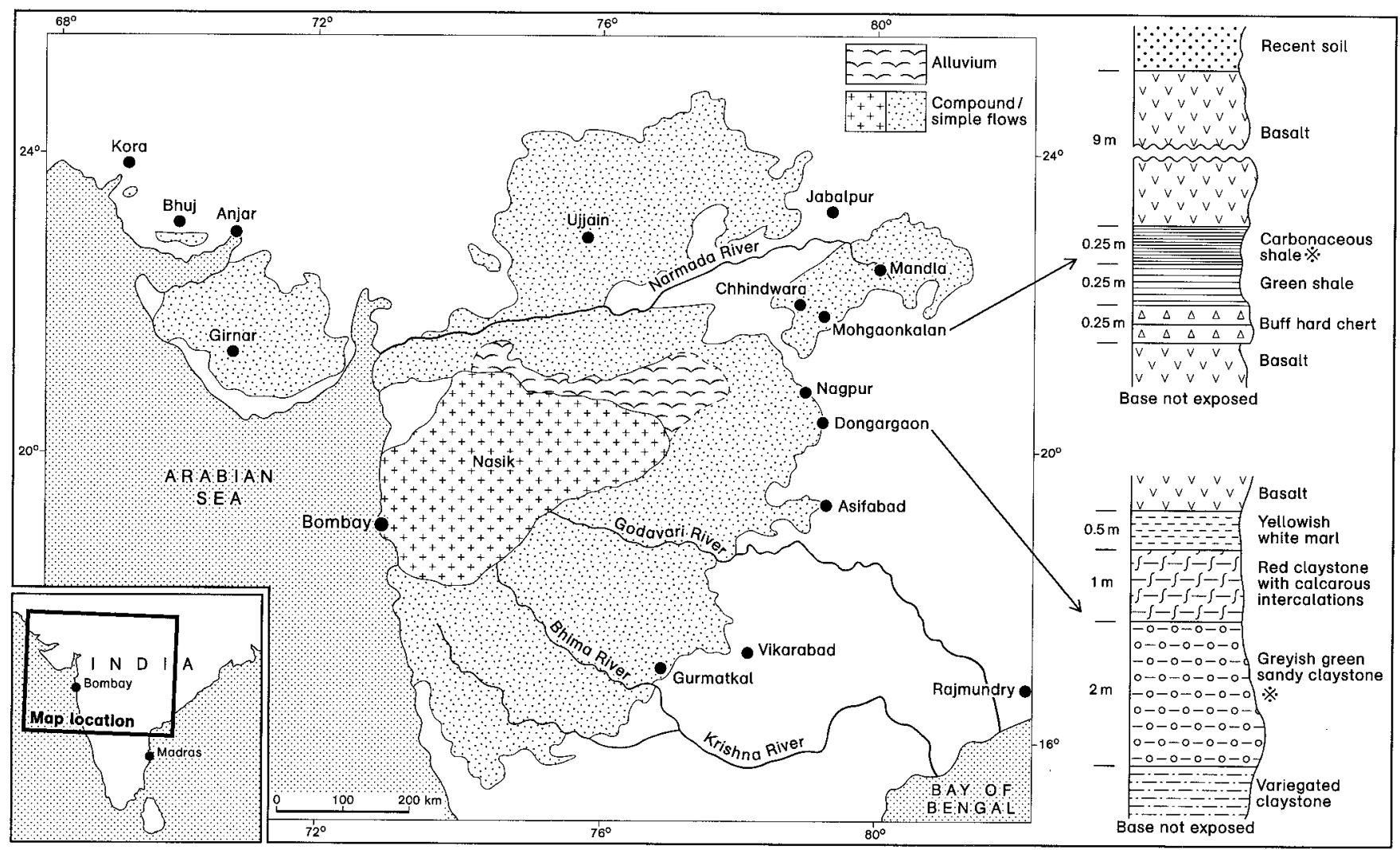

Fig. 1. Location map showing the outcrop of the Deccan Traps and the major localities cited in the text.

specific level they clearly constitute an endemic Indian fauna. In other respects, they exhibit as much affinity with African and European late Cretaceous ostracods as they do with other Asian faunas. Chinese and Mongolian faunas, while containing representatives of most of the genera which occur in India, are dominated by Cypridea, its allies and descendents. Cypridea and allies, however, are absent from most contemporary Indian faunas and, where they do occur, they are always very subordinate. Only one species, Frambocythere tumiensis, is common to both the Indian and Chinese (Ye in Hou et al., $1982=$ Bisulcocypris fangjiaheenensis Chen, 1956; Hou et al., 1978, 1982; Yang et al., 1989) Upper Cretaceous, but they are different sub-species. Mongolocypris cf. M. gigantea Ye et al., 1977, a gigantic species (up to $4.12 \mathrm{~mm}$ in length), described by Khosla \& Sahni (2000) from the Maastrichtian Lameta Formation of Jabalpur, is very close to the Chinese species from the Maastrichtian of Yunnan and to M. distributa Szczechura, 1978, a contemporary species from the Gobi Desert. However, in all our studies of Indian intertrappean ostracods, we have only ever encountered a single, very poorly preserved specimen of this species, although the Lameta Formation yielded 110 specimens to Khosla \& Sahni. It is a rare constituent of the Indian Upper Cretaceous.

The Indian intertrappean Cypridacea are quite similar to contemporary African and European taxa, although no species seem to occur in common. However, the abundant and diverse species of the cytherid Gomphocythere Sars in the Indian fauna are some somewhat similar to such African species as
Cytheridella sp. of Colin et al. (1997) from the Upper Cretaceous of Mali, West Africa and even to such species as Theriosynoecum camerounensis Colin, 1992 from the Aptian/Albian of Cameroun and a number of species, referred to variously as Theriosynoecum and Metacypris Brady \& Robertson, by Colin \& Dépêche (1997, pl. 5) from Chad. Theriosynoecum silvai (Silva, 1978) and T. munizi (Silva, 1978) from the contemporary and almost adjacent Aripe Basin in Brazil are also similar in some respects.

The age of the fauna is late Cretaceous, Maastrichtian. Apart from the three new species, the remaining six species are widespread at other Maastrichtian intertrappean localities whose absolute age is known from radiometric dates obtained on the basalt flows that constrain them. Many species are also shared with the Maastrichtian Lameta Formation, which is stratigraphically contiguous with the intertrappeans but is not constrained by lava flows. A feature of the Upper Cretaceous ostracod faunas of the intertrappeans, is that each new locality studied seems to contain a percentage of new species, which often subsequently prove to be to a certain degree endemic while the remainder are more geographically widespread, perhaps more tolerant taxa. To what extent this is environmental/ ecological and to what extent truly zoogeographical is a moot point. The differences in the faunas of even quite closely adjacent localities do not, however, seem to be due to their being of different ages, largely because of the wealth of radiometric dates available.

Further work on the intertrappean Ostracoda is in hand. Important collections of intertrappean Ostracoda made by 
British natural historians in the mid to late nineteenth century have recently come to light in the Natural History Museum, and these are the subject of two taxonomic studies (Whatley et al., in press c,d) and a number of new records of species from previously studied localities and new taxa from these and additional localities are the basis of two studies (Whatley et al., in press $\mathrm{a}, \mathrm{b})$. The senior authors are completing a comprehensive review of Indian intertrappean Ostracoda, with particular reference to their age, palaeoecology, zoogeographical distribution affinities and evolution (Whatley \& Bajpai, in prep.).

\section{SYSTEMATIC DESCRIPTIONS}

All type and figured specimens are deposited in the Bajpai collection in the museum of the Department of Geology, Roorkee University, with catalogue numbers prefixed RUSB. The following conventions are employed: RV, right valve; $L V$, left valve; C, articulated carapace; A, adult; juv., juvenile, rpc, radial pore canal; npc, normal pore canal. All dimensions are in millimetres and the size convention for the length of adults, as used by the senior author over many years for podocopid ostracods is as follows: $<0.40 \mathrm{~mm}$, very small; $0.40-0.50 \mathrm{~mm}$, small; $0.50-0.70 \mathrm{~mm}$, medium; $0.70-1.00 \mathrm{~mm}$, large; $>1.0$, very large.

Phylum Crustacea Pennant, 1777

Class Ostracoda Latreille, 1806

Order Podocopida Müller, 1894

Suborder Podocopina Müller, 1894

Superfamily Cytheracea Baird, 1850

Family Limnocytheridae Klie. 1938

Subfamily Timiriaseviinae Mandelstam, 1960

Genus Frambocythere Colin, 1980

Frambocythere tumiensis (Helmdach, 1978).

Frambocythere tumiensis lakshmiae Whatley \& Bajpai, 2000a (Pl. 1, fig. 2)

2000a Frambocythere tumiensis lakshmiae Whatley \& Bajpai: 390 , pl. 1, figs 6-15.

Type species. Bisulcocypris tumiensis Helmdach, 1978.

Material. Three specimens.

Dimensions. Female C, RUSB 6130 - length, 0.35; width, 0.31.

Occurrence. This is the second occurrence of this species. The original material was from the Maastrichtian of Lakshmipur in Kachchh.

Remarks. This sub-species differs from $F$. tumiensis anjarensis Bhandari \& Colin, 1999 in that the anterior margin is more rounded, the large papillate tubercles on the dorsal part of the antero-marginal area are absent and the papillae paralleling the posterior part of the dorsal margin are much less pronounced. It is debatable whether or not the various recorded sub-species of Frambocythere tumiensis would not be better considered as separate species. Certainly the present species differs sufficiently from the type material of Helmdach (1978) for separate specific status to be seriously considered.

\section{Genus Gomphocythere Sars, 1924}

Remarks Gomphocythere Sars and Cytheridella Daday are somewhat similar genera in external carapace morphology. It is certainly difficult to distinguish the genera when only carapaces are available for study, although their hinges are different. The former has a reversed lophodont hinge, with the terminal bar in the LV, while the latter has normal lophodont hingement. It is, of course, arguable that hinge reversal is not necessarily a generic characteristic, since it is common in some genera and even some species. There is something of a convention that, with fossil taxa, Mesozoic species are usually referred to Gomphocythere, while Cenozoic species are placed in Cytheridella. This is to be noted in the title of such papers as Colin, J.-P. et al. (1997) 'An early record of the genus Cytheridella Daday, 1905 (Ostracoda, Limnocytheridae, Timiriaseviinae) from the Upper Cretaceous of Mali, West Africa ...' where 'early' is the operative word. It is also the case that, generally speaking, Mesozoic species of Gomphocythere are more heavily ornamented than Cenozoic species of Cytheridella. The West African species of Colin et al. (1997), Cytheridella sp., is noted by these authors (p. 93) because 'Besides minor details of the outline, the Malian Upper Cretaceous species differs from other known species of the genus by its strong ornamentation formed by numerous small and deep polygonal pits'. Since their specimens were all carapaces, they were also unable to see the hinge. In fact, in our opinion this African species is Gomphocythere and quite close to some of the species we have encountered in the intertrappeans.

Gomphocythere paucisulcatus sp. nov. (Pl. 1, figs 1-6)

1999 Gomphocythere ? sp. 1 Bhandari \& Colin: 13, pl. 1, figs 11-13.

?1995 MS Timiriasevia cf. T. minuscule (sic) Singh: pl. 19, figs $\mathrm{g}-\mathrm{i}$.

?1995 MS Timiriasevia sp. indet. Singh: pl.19, figs j-i.

Type species. Limnicythere obtusata Sars, 1924.

Derivation. L. paucisulcatus weak-furrow. With reference to the very poorly developed median sulcus in this species.

Diagnosis. A medium species of Gomphocythere, not strongly inflated, almost equally acuminate at each end and with a very slight median sulcus.

Holotype. Male C, RUSB 6131.

Material. Five specimens in the present study, six specimens in the study of Bhandari \& Colin (1999) and possibly a number of specimens illustrated by Singh (1995 MS) from Bombay.

Type locality and level. Mohagaonkala. Well spoil, Maastrichtian carbonaceous shale below lava flow.

Description. Medium. Sexually dimorphic, the females with a rather slight brood swelling. Subovate to subrectangular in 


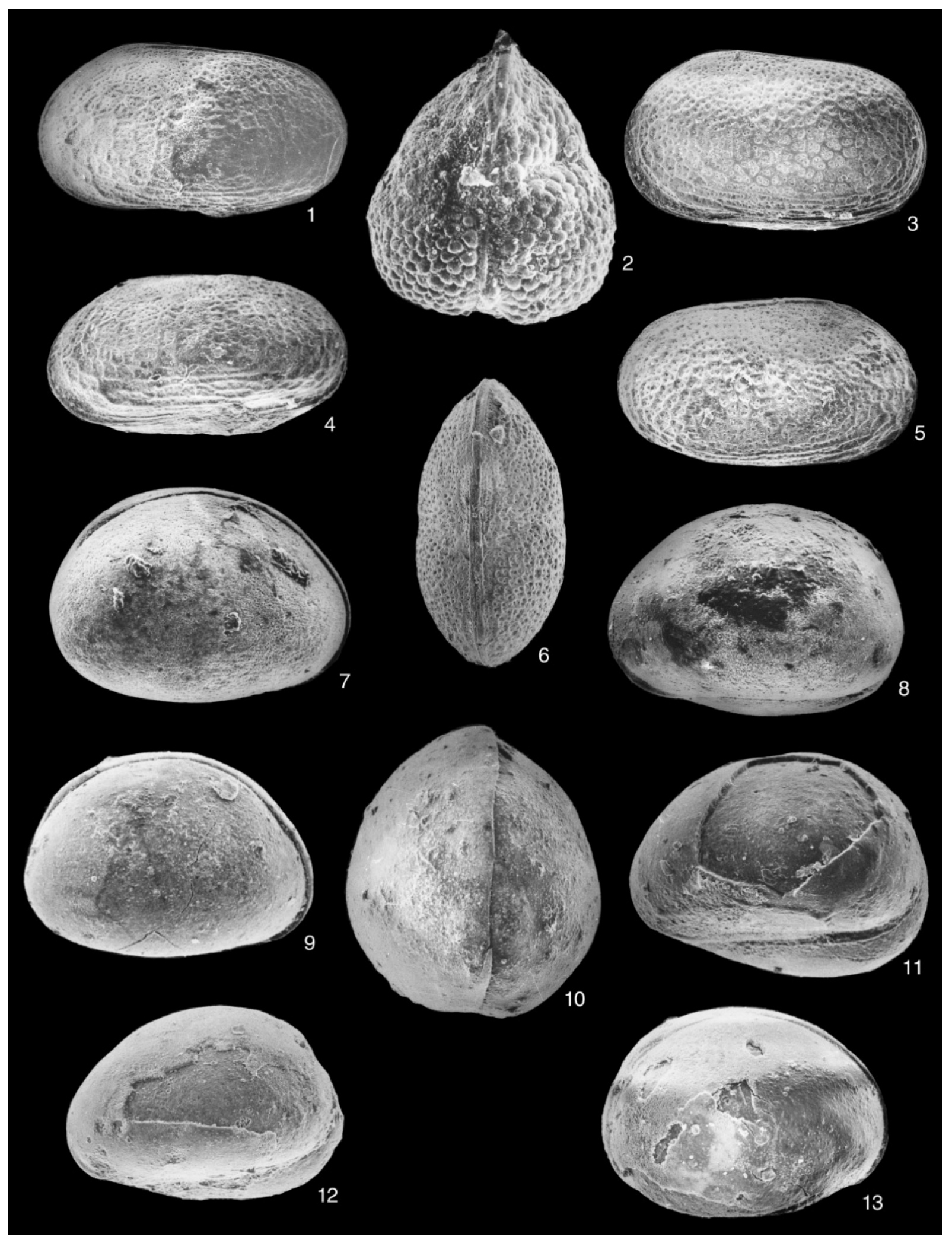

Explanation of Plate 1.

figs 1, 3-6. Gomphocythere paucisulcata sp. nov.: 1, holotype, RUSB 6131, male carapace, left lateral view, $\times 91$; 3, paratype, RUSB 6132, female carapace, left lateral view, $\times 98 ; \mathbf{4}$, paratype, RUSB 6133, male carapace, left lateral oblique view, $\times 90 ; \mathbf{5}$, paratype, RUSB 6135 , female carapace, right lateral view, $\times 100 ; \mathbf{6}$, paratype, RUSB 6134, female carapace, dorsal view, $\times 96$. fig. 2. Frambocythere tumiensis lakshmiae Whatley \& Bajpai, 2000; RUSB 6130, female carapace, dorsal view, $\times 146$. figs 7-13. Cypridopsis elachistos sp. nov.: 7, holotype, RUSB 6137, carapace, right lateral view, $\times 115 ; 8$, paratype, RUSB 6138, carapace, left lateral view, $\times 113 ; \mathbf{9}$, paratype, RUSB 6143, carapace, right lateral view, $\times 118$; 10, paratype, RUSB 6140, carapace, dorsal view, $\times 119$; 11, paratype, RUSB 6145, carapace, left lateral view, $\times 119$; 12, paratype, RUSB 6141, carapace, left lateral oblique view, $\times 112 ; 13$, paratype, RUSB 6144 , carapace, left lateral view, $\times 111$. 
lateral view. In dorsal view subfusiform, with anterior only a little more acuminate anteriorly than posteriorly, not strongly inflated and with only slight trace of median sulcus. Anterior margin well rounded but with antero-dorsal slope long and almost straight; apex a little below mid-height. Posterior margin more symmetrically rounded, with apex at or just above midheight. Dorsal margin long and straight, dorsal cardinal angles subrounded. Ventral margin with slight oral concavity. Median sulcus almost at mid-length and very feebly developed. Ornament of large reticulae, with between 1 and 4 secondary puncta within fossae. Some small conjunctive pore conuli occur across the valve. The concentric muri of the reticulum dominate around the free margins, resulting in a number of parallel ribs paralleling the margins. A weak rib parallels the dorsal margin. A weak marginal rim is developed anteriorly. LV slightly larger than RV. Internal features not seen, except for the external impression of four vertical adductor scars seen in some specimens.

\section{Dimensions.}

Specimen

Holotype male C, RUSB 6131

Paratype female C, RUSB 6132

Paratype male C, RUSB 6133

Paratype female C, RUSB 6134

Paratype female C, RUSB 6135

$\begin{array}{ll}\text { Length } & \text { Height } \\ 0.58 & 0.32 \\ 0.52 & 0.30 \\ 0.58 & 0.32 \\ 0.52 & \end{array}$

Width

0.52

0.30

Occurrence. Known from the type locality, from the Maastrichtian of Anjar, Kutch (Bhandari \& Colin, 1999) and possibly from the Maastrichtian intertrappeans of Bombay (Singh, 1995 MS).

Remarks. The material described by Bhandari \& Colin (1999) is identical in all respects as noted in their description: '... caractérisée par sa petite taille, un sulcus peu différencié, un surface réticulée ...'. The dimensions given by these authors are: female $\mathrm{L}=0.54, \mathrm{H}=0.33$; male $\mathrm{L}=0.57, \mathrm{H}=0.31$. Both Timiriasevia cf. T. miniscula (the author of minuscula is not given but is presumably Stankevitch, in Stankevitch \& Sochava, 1974) and Timiriasevia sp. indet. of Singh (MS, 1995), are possibly the same as the present species, although they are rather larger $(\mathrm{L}=0.65-0.70)$. The authors will reexamine this material soon. Gomphocythere akalyptos Whatley et al. (2002) is only a little larger than the present species but has a reticulum of smaller fossae, a very strongly developed median sulcus, is strongly inflated and much more acuminate anteriorly than posteriorly. Gomphocythere dasyderma Whatley et al. (2002) is also rather larger, has different ornament and a much stronger median sulcus. G. strangulata (Jones) is much larger and has a very strong median sulcus. G. gomphotatos Whatley \& Bajpai, 2000a is considerably larger, has a much more delicate ornament and is strongly sulcate. Gomphocythere sp. of Whatley \& Bajpai (2000a) is also much larger and has punctate ornament, is sulcate and has a strong subponticulate ventro-lateral rib.

Superfamily Cypridacea Baird, 1845

Family Cyprididae Baird, 1845

Subfamily Cypridinae Baird, 1845
Genus Paracypretta Sars, 1924

Paracypretta bhatiai (Khosla \& Sahni, 2000)

(Pl. 2, fig. 10)

1990b Altanicypris szczechurae (Stankevitch) Bhatia et al.: 118, pl. 1, figs 9, 10 .

1994 Altanicypris sp. Sahni \& Kohsla: 458, figs 2n-p.

2000 Altanicypris bhatiai sp. nov. Kohsla \& Sahni: 58, fig. 1a-g. 2000b Paracypretta bhatiai (Kohsla \& Sahni) Whatley \& Bajpai: 174, pl. 1, figs $1-3$.

2000 Altanicypris. Bajpai \& Prasad: 258, fig. 2f.

2002 Paracypretta bhatiai (Kohsla \& Sahni). Whatley et al.: pl. 3, figs 1-5.

Non 1974 Cypridea szczechurae Stankevitch (in Stankevitch \& Sochava): 276, pl. 1, fig. 5.

Non 1978 Altanicypris szczechurae (Stankevitch) Szczechura: 91, pl. 21, figs $2-5$, pl. 37, fig. 3 (and synonomy).

Non 1990a Altanicypris szczechurae (Stankevitch) Bhatia et al.: 47, pl. 1, figs $1-7$.

Non 1996 Altanicypris szczchecurae (Stankevitch) Bhatia et al.: 305 , pl. 1, figs $1-7$.

Type species. Paracypretta ampullacea Sars, 1924.

Material. Five articulated carapaces.

Dimensions. Female C, RUSB 6136 - length, 1.49; height, 0.98; width, 0.94 .

Occurrence. This species is fairly widely distributed in the Upper Cretaceous intertrappean beds of Peninsular India. It did not occur, however, at either Lakshmipur (Whatley \& Bajpai, 2000a) or Kora (Bajpai \& Whatley, 2001), although we recorded it at Anjar (Whatley \& Bajpai, 2000b) from which locality Bhandari \& Colin (1999) failed to register it. We also record it from both Chandarki and Yanagundi (Whatley et al. 2002).

Remarks. The original material of Paracypretta subglobosa (Sowerby) has recently been encountered in the Natural History Museum. It is certainly very close to the present species and their relationship will be discussed in a forthcoming study (Whatley et al., in press a).

\section{Subfamily Cypridopsinae Kaufmann, 1960 Genus Cypridopsis Brady, 1868 \\ Cypridopsis elachistos sp. nov. (Pl. 1, figs 7-13; Pl. 2, figs 1, 2)}

Type species. Cypris vidua O. F. Müller, 1776.

Derivation. Gr. $\varepsilon \lambda \alpha \chi 1 \sigma \tau \circ \varsigma$ least, smallest. With reference to the fact that the present species is by some considerable margin, the smallest of the genus Cypridopsis to be so far recorded from Indian Upper Cretaceous intertrappean deposits.

Diagnosis. A small, minutely punctate, very globular species of Cypridopsis with LV larger than RV and with considerable overlap around the entire periphery. 


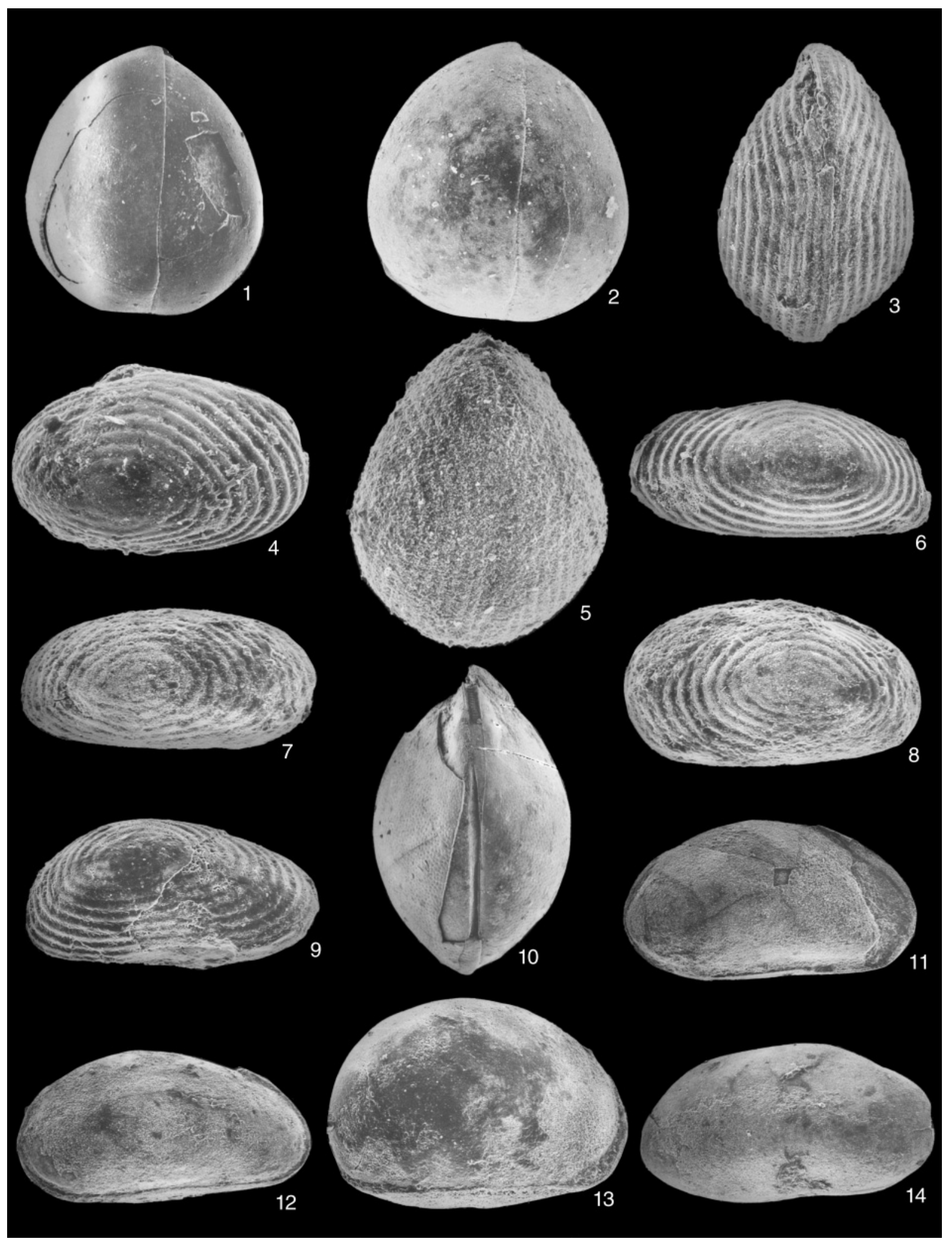

Explanation of Plate 2.

figs 1, 2. Cypridopsis elachistos sp. nov.: 1, paratype, RUSB 6139, carapace, dorsal view, $\times 104$; 2, paratype, RUSB 6142, carapace, dorsal view. figs 3-9. Zonocypris labyrinthos sp. nov.: 3, paratype, RUSB 6148, male carapace, dorsal view $\times 130 ;$ 4, paratype, RUSB 6152 , female carapace, right lateral oblique view, $\times 150 ; \mathbf{5}$, paratype, RUSB 6151 , female carapace, ventral view, $\times 157 ; \mathbf{6}$, paratype, RUSB 6150 , male carapace, left lateral view, $\times 147 ; 7$, paratype, RUSB 6147 , male carapace, right lateral view, $\times 125 ; 8$, holotype, RUSB 6146, female carapace, left lateral view, $\times 142,9$, paratype, RUSB 6149, female carapace, right lateral view, $\times 138$. fig. 10. Paracypretta bhatiai Khosla \& Sahni, 2000; RUSB 6136, female carapace, dorsal view, $\times 34$. fig. 11. Eucypris pelasgicos Whatley \& Bajpai, 2000, RUSB 6154, A-2 juvenile carapace, right lateral view, $\times 68$. fig. 12. Eucypris intervolcanus Whatley \& Bajpai, 2000, RUSB 6155, carapace, right lateral view, $\times 60$. fig. 13. Cypria cyrtonidion Whatley \& Bajpai, 2000, RUSB 6157, carapace, right lateral oblique view, $\times 86$. fig. 14. Mongolianella sp., RUSB 6156, carapace, right lateral view, $\times 64$ 
Holotype. Carapace, RUSB 6137.

Material. Twenty specimens.

Type locality and level. Mohagaonkala. Well spoil, Maastrichtian carbonaceous shale below lava flow.

Description. Small. Subovate in lateral view. Very strongly inflated in dorsal view, with maximum width in the posterior third and very truncated posterior. Carapace almost as wide as it is long and notably wider than it is high. Anterior margin rather narrowly and asymmetrically rounded, with strongly convex antero-ventral and longer, almost straight antero-dorsal slope; apex below mid-height. Posterior margin very bluntly pointed at mid height and with symmetrical postero-dorsal and postero-ventral slopes. Dorsal margin regularly convex, with greatest height at mid-length. Ventral margin obscured in lateral view by valve tumidity; oral incurvature shallow. Surface smooth or with some minute puncta. Sexual dimorphism not observed. Internal features not seen.

$\begin{array}{lll}\text { Dimensions. } & & \\ \text { Specimen } & \text { Length } & \text { Height } \\ \text { Holotype C, RUSB 6137 } & 0.45 & 0.33 \\ \text { Paratype C, RUSB 6138 } & 0.45 & 0.32 \\ \text { Paratype C, RUSB 6139 } & 0.45 & 0.32 \\ \text { Paratype C, RUSB 6140 } & 0.43 & 0.31 \\ \text { Paratype C, RUSB 6141 } & 0.43 & 0.33 \\ \text { Paratype C, RUSB 6142 } & 0.42 & 0.31 \\ \text { Paratype C, RUSB 6143 } & 0.42 & 0.35 \\ \text { Paratype C, RUSB 6144 } & 0.44 & 0.33 \\ \text { Paratype C, RUSB 6145 } & 0.43 & 0.32\end{array}$

Width

0.41

0.41

Occurrence. Apparently confined to the type locality.

Remarks. The present species is much smaller than Cypridopsis palaichthonous Bajpai \& Whatley (2001), from the Upper Cretaceous intertrappeans of Kora, which ranges in length from 0.86-0.95, and is also much more inflated. Cypridopsis wynnei Whatley \& Bajpai, 2000a is larger than the present species $(\mathrm{L}=0.83-0.90)$, is strongly sexually dimorphic and much less regularly subovate. Cypridopsis hyperectyphos Whatley \& Bajpai, $2000 \mathrm{a}$ is even more strongly inflated, somewhat larger $(\mathrm{L}=0.52-$ 0.61 ) and delicately punctate. The latter two species are from the Upper Cretaceous intertrappeans of Lakshmipur. Cypridopsis buginstavicus (Stankevitch, 1974), from the Mongolian Upper Cretaceous, is twice as large, although somewhat similar in shape. Cypridopsis astralos Whatley et al. (2002), from the Upper Cretaceous intertrappeans of Yanagundi and Chandarki, is half as large again, much less inflated and is reticulate/ tuberculate. Cyclocypris transitoria Stankevitch, from Mongolia, is a little smaller $(\mathrm{L}=0.37-0.39)$, much less inflated and not truncated posteriorly in dorsal view. Cyclocypris sahnii Bajpai \& Whatley, 2000b from Jabalpur and Kora is much larger $(\mathrm{L}=0.60-0.73)$, much less symmetrically subovate and less concave ventrally. Cyclocypris amphiboles Whatley \& Bajpai (2002) from Yanagundi is less inflated, has a very different shape in lateral view and is larger $(\mathrm{L}=0.50-0.56)$.

Genus Zonocypris Müller, 1898

Zonocypris labyrinthicos $\mathrm{sp}$. nov.

(P1. 2, figs 3-9)
Type species. Zonocypris madagascarensis G. W. Müller, 1898.

Derivation. Gr. $\lambda \alpha \beta u \rho v v \theta \omega \varsigma$ the labyrinth. From the resemblance of the concentrically spiral ornament of this species to a maze or labyrinth.

Diagnosis. A small, rather elongate species of Zonocypris, characterized by a concentrically spiral ornament which arises from a rather smooth central area.

Holotype. A female carapace, RUSB 6146.

Material. Thirteen specimens.

Type locality and level. Mohagaonkala. Well spoil, Maastrichtian carbonaceous shale below lava flow.

Description. Small. Elongate subovate in lateral view. Very strongly inflated in dorsal view in females, more fusiform in males. Anterior margin rather narrowly rounded; posterior margin even more so. Dorsal margin gently arched in males, more strongly convex in females. Ventral margin appears straight in lateral view but with slight oral concavity when seen ventrally. Greatest length at mid-height; greatest height at mid-length; greatest width behind mid-length. Ornament concentrically spiral rib which arises from a central locus which is smooth or virtually so. Normal pore canal openings occur on the spiral rib. RV larger than LV. Internal features not seen.

$\begin{array}{llll}\text { Dimensions. } & & & \\ \text { Specimen } & \text { Length } & \text { Height } & \text { Width } \\ \text { Holotype female C, RUSB 6146 } & 0.36 & 0.21 & \\ \text { Paratype male C, RUSB 6147 } & 0.40 & 0.20 & \\ \text { Paratype male C, RUSB 6148 } & 0.40 & 0.20 & 0.25 \\ \text { Paratype female C, RUSB 6149 } & 0.36 & 0.20 & \\ \text { Paratype male C, RUSB 6150 } & 0.36 & 0.17 & \\ \text { Paratype female C, RUSB 6151 } & 0.34 & & 0.27 \\ \text { Paratype female C, RUSB 6152 } & 0.34 & 0.20 & \\ \text { Paratype female C, RUSB 6153 } & 0.38 & & 0.30\end{array}$

Occurrence. Apparently confined to the type locality.

Remarks. This species differs from Z. gujaratensis Bhandari \& Colin, 1999 in being 25\% longer, in lacking the very angular initial coils in its spiral ornament and in the different pattern of the coil. From Z. spirula Whatley \& Bajpai, 2000a it differs in being between $20 \%$ and $25 \%$ larger, more elongate and rather less inflated. From both the above species, from the Upper Cretaceous of Kachchh, it differs in its absence of defined early whorls in its ornament.

Subfamily Eucypridinae Bronshtein, 1947 Genus Eucypris Vávra, 1891

Eucypris pelasgicos Whatley \& Bajpai, 2000 (Pl. 2, fig. 11)

?1965 Eucypris sp. Khanna \& Mohan: fig 2, 1. 1990a Candona altanulaensis Szczechura \& Blaszyk; Bhatia et al.: pl. 3, fig. 3 . 
1996 Candona altanulaensis Szczechura \& Blaszyk; Bhatia et al.: 297, pl. 3, fig. 3.

2000a Eucypris pelasgicos sp. nov. Whatley \& Bajpai: 400, pl. 5, figs $7-15$.

2001 Eucypris pelasgicos Whatley \& Bajpai; Bajpai \& Whatley: 102, pl. 2, fig. 15; pl. 3, figs 1-3.

Non 1970 Candona altanulaensis Szczechura \& Blaszyk: 114, pl. 29, figs 2, 4 .

Type species. Monoculus virens Jurine, 1820.

Material. A single juvenile specimen.

Dimensions. A-2 juv. C, RUSB 6154 - length, 0.75; height, 0.41.

Occurrence. Previously recorded from the intertrappean deposits of Lakshmipur (Khanna \& Mohan, 1965; Whatley \& Bajpai, 2003), Kora (Bajpai \& Whatley, 2001) and Takli, (Bhatia et al., 1990a, 1996).

Remarks. This species differs from Candona altanualensis Szczechura \& Blaszyk, 1971 from the Upper Cretaceous of Mongolia in being considerably larger $(\mathrm{L}=0.83, \mathrm{H}=0.44)$. and in its angular antero-ventral corner. The former species also has a much more posteriorly situated dorsal apex and truncated posterior, and is probably a true Candona. Eucypris sp. of Khanna \& Mohan (1965) is possibly conspecific with the present material.

\section{Eucypris intervolcanus Whatley \& Bajpai, 2000a}

$$
\text { (Pl. 2, fig. 12) }
$$

2000a Eucypris intervolcanus sp. nov. Whatley \& Bajpai: 401, pl. 5, figs 16-19.

2001 Eucypris intervolcanus Whatley \& Bajpai; Bajpai \& Whatley: 103, pl. 3, figs 4, 7 .

2002 Eucypris intervolcanus Whatley \& Bajpai; Whatley et al.: pl. 4, fig. 11.

Material. Two carapaces.

Dimensions. C, RUSB 6155 - length, 0.83; height, 0.43 .

Occurrence. Previously known only from Lakshmipur (Whatley \& Bajpai, 2000a), Yanagundi (Whatley et al., 2002) and Kora (Bajpai \& Whatley 2001).

Remarks. The present specimen is of exactly the same size as the holotype from Lakshmipur and the material from Yanagundi, but rather larger than that from Kora.

Subfamily Herpetocypridinae Kaufmann, 1900

Genus Mongolianella Mandelstam, 1956

Mongolianella sp.

(Pl. 2, fig. 14)

1999 Mongolianella sp. 2 Bhandari \& Colin: 16, pl. 2, fig. 11.

Type species. Mongolianella palmosa Mandelstam, 1956.
Diagnosis. A very large, subcylindrical species of Mongolianella with a dorsal margin in which the central part is straight and the cardinal angles both marked.

Material. Two specimens.

Dimensions. C, RUSB 6156 - length, 1.22; height, 0.58 .

Occurrence. Other than the present locality, this species has been recorded from Anjar in Kachchh.

Remarks. The specimen described by Bhandari \& Colin (1999) is somewhat more cylindrical than the present individual, but they are probably conspecific. There is a problem concerning the relationship of this species with $M$. cylindrica Sowerby. This was originally (1840) stated to be one-eighth of an inch or $3.175 \mathrm{~mm}$ in length. However, Jones (1860, p. 186), who reviewed Sowerby's material, thought 'perhaps this may have arisen from an error of the engraver'. Jones did not encounter any individual larger than one-twentieth of an inch $(1.27 \mathrm{~mm})$. Our extensive collection (>100 individuals) of well preserved material from Lakshmipur contained several specimens longer than $1 \mathrm{~mm}$, but the largest was $1.19 \mathrm{~mm}$. However, the assemblage exhibited distinct sexual dimorphism and there is no doubt that the larger specimens were adult. The type material of Sowerby in the NHM London, which is the subject of a current revision (Whatley et al., 2003a) contains a number of large specimens, including one which is $1.27 \mathrm{~mm}$ long. This is possibly the largest individual measured by Jones. The present specimen could, on grounds of size, belong to M. cylindrica, but the end margins are generally less well rounded and the dorsal margin more angular than any member of the type collection. Bhandari \& Colin's (1999) specimen at $1.50 \mathrm{~mm}$ is clearly rather large for $M$. cylindrica and, for the moment, for the reasons stated above, these two specimens are retained in Mongolianella sp.

\section{Subfamily Cyclocypridinae Zenker, 1854 Genus Cypria Zenker, 1854}

Cypria cyrtonidion Whatley \& Bajpai, 2000

$$
\text { (Pl. 2, fig. 13) }
$$

1984 Cyprois sp. Bhatia \& Rana: 33, pl. 2, fig. 12.

1988 Cyprois sp. Mathur \& Verma: 173, pl. 1, figs 1, 2.

2000a Cypria cyrtonidion sp. nov. Whatley \& Bajpai: 404, pl. 6, figs 9-14.

2001 Cypria cyrtonidion Whatley \& Bajpai; Bajpai \& Whatley: 101, pl. 2, figs 7-9.

2002 Cypria cyrtonidion sp. nov. Whatley \& Bajpai; Whatley et al.: pl. 6, fig. 19.

Type species. Cypris exsculpta Fischer, 1854.

Material. Two carapaces.

Dimensions. C, RUSB 6157 - length, 0.59; height, 0.42 .

Occurrence. Previously described by Whatley \& Bajpai (2000a) from the intertrappean beds of Lakshmipur, from Yanagundi 
and Chandarki (Whatley et al., 2002) and by Bajpai \& Whatley (2001) from Kora. Mathur \& Verma (1988) record the species from SE Rajasthan and Bhatia \& Rana (1984) from Gitti Khadan, near Nagpur.

Remarks. This characteristically 'hunchbacked' species is readily distinguished. The present figured specimen is somewhat longer than the largest of the type material from Lakshmipur (0.57).

\section{ACKNOWLEDGEMENTS}

Srinivasan wishes to acknowledge the help and encouragement he has received from Professor Ashok Sahni who, as his PhD supervisor, introduced him to the study of the intertrappeans of this area. We thank Dr J. E. Whittaker of the Department of Palaeontology, Natural History Museum, London for much valued assistance. We wish to thank the two anonymous referees for some valuable comments and their careful corrections.

\section{Manuscript received 25 June 2001 Manuscript accepted 24 January 2002}

\section{REFERENCES}

Bajpai, S. \& Prasad, G.V.R. 2000. Cretaceous age for Ir-rich Deccan intertrappean deposits: palaeontological evidence from Anjar, western India. Journal of the Geological Society, London, 157: 257-260.

Bajpai, S. \& Whatley, R.C. 2001. Late Cretaceous non-marine ostracods from the Deccan Intertrappean beds, Kora (Western Kachchh, India). Revista Española de Micropalaeontología, 33(1): 91-111.

Bande, M.B., Chandra, A., Venkatchala, B.S. \& Mehrotra, R.C. 1988. Deccan Traps floristics and their stratigraphic implications. Proceedings, Symposium on Palaeocene of India: Limits and Subdivisions, Indian Association of Palynostratigraphers, Lucknow: 83-123.

Bhandari, A. \& Colin, J.-P. 1999. Ostracodes limniques des sédiments inter- état trappéens (Maastrictien terminal-Paléocene basal) de la région d'Anjar (Kachchh, Etat de Gujarat), Inde: systématique, paléoécologie et affinités paléobiogéographiques. Revue de Micropaléontologie, 42(1): 3-20.

Bhatia, S.B. \& Rana, R.S. 1984. Palaeogeographic implications of the charaphyta and Ostracoda of the intertrappean beds of peninsular India. Mémoire de la Societé géologique de France, Paris, 147: 29-36.

Bhatia, S.B., Prasad, G.V.R. \& Rana, R.S. 1990. Deccan volcanism, a late Cretaceous event; conclusive evidence of Ostracodes. In: Sahni, A. \& Jolly, A. (Eds), Cretaceous event stratigraphy and the correlation of the Indian non-marine strata. Contributions from the Seminar cum Workshop, I.G.C.P. $216 \& 245$, Chandigarh: 47-49.

Bhatia, S.B., Srinivasan, S., Bajpai, S. \& Jolly, A. 1990. Microfossils from the Deccan intertrappean bed at Momoni District, Kota, Rajasthan; additional taxa and age implications. In: Sahni, A. \& Jolly, A. (Eds), Cretaceous event stratigraphy and the correlation of the Indian non-marine strata. Contributions from the Seminar cum Workshop, I.G.C.P. 216 \& 245, Chandigarh: 118-119.

Bhatia, S.B., Prasad, G.V.R. \& Rana, R.S. 1996. Maastrichtian nonmarine ostracodes from Peninsular India: palaeobiogeographic and age implications'. Memoir of the Geological Society of India., 37: 297-311.

Chen, T-C. 1956. The ostracod genus Metacypris and its allies. (In Chinese with English abstract) Acta Palaeontologica Sinica, 13: 1-28.

Colin, J.-P. \& Dépêche, F. 1997. Faunes d'ostracodes lacustres des bassins intra-cratoniques d'age albo-aptien en Africa de l'Ouest (Cameroun, Tchad) et au Brésil: considérations d'ordre paléoécologique et paléobiogéographique. Africa Geoscience Review, 4(3,4): 431-450.

Colin, J.-P., Tambareau, Y. \& Krasheninnkov, V.A. 1997. An early record of the genus Cytheridella Daday, 1905 (Ostracoda, Limnocytheridae, Timiriaseviinae) from the Upper Cretaceous of Mali, West Africa: palaeobiolgeographical and palaeoecological considerations. Journal of Micropalaeontology, 16: 91-95.
Helmdach, F.F. 1978. Möglichkeiten der Verbreitung nichtmariner Ostrakodenpopulationen und deren Auswirkung auf die Phylogenie und die Stratigraphie. Neues Jahrbuch für Geologie und Paläontologie. Stuttgart. Monatshefte, 6: 378-384.

Hou, Y-T., Ho, J-D. \& Ye, C.H. 1978. The Cretaceous-Tertiary ostracods from the marginal region of the Yangtse-Han River Plain in Central Hubei. (In Chinese with English abstract) Memoire of the Nanjing Institute of Geology and Palaeontology, Academica Sinica, 9: 129-238.

Hou, Y-T., Chen, T-C., Yang, H.R., Ho, J-D., Zhao, Q-C. \& Tian, M-Q. 1982. (In Chinese with English abstract) Cretaceous-Quaternary ostracod fauna from Jiangsu. Geological Publishing House, Beijing, $1-386$.

Jaegar, J.J., Courtlot, V. \& Tapponier, P. 1989. Paleontological view of the ages of the Deccan Traps, the Cretaceous-Tertiary boundary and India-Asia collision. Geology, 17: 316-391.

Jones, T.R. 1860. Notes on the fossil Cypridae. In: Hislop, S. (Ed.). Quarterly Journal of the Geological Society, London, 16: 154-189.

Kar, R.K. \& Srinivasan, S. 1998. Late Cretaceous palynofossils from the Deccan Intertrappean beds of Mohaogon-Kalan, Chhindwara District, Madhya Pradesh. Geophytology, 27(1\&2): 17-22.

Khanna, S.N. \& Mohan, M. 1965. Intertrappean beds of Kutch, Western India. Bulletin of the Geological Society of India, 2: 48-51.

Khosla, A. \& Sahni, A. 2000. Late Cretaceous (Maastrichtian) ostracodes from the Lameta Formation, Jabalpur Cantonment, Madhya Pradesh, India. Journal of the Palaeontological Society of India, 45: 57-78.

Mathur, A.K. \& Verma, K.K. 1988. Freshwater ostracodes from the intertrappean of southeastern Rajasthan. Geological Survey of India Special Publication, 11(2): 169-174.

Prasad, G.V.R. \& Rage, J.C. 1991. A discoglossid frog in the late Cretaceous (Maastrichtian) of India. Further evidence for a terrestrial route between India and Laurasia in the latest Cretaceous. Comptes rendus de l'Académie des Sciences de Paris, 313: 273-278.

Sahni, A. \& Bajpai, S. 1991. Eurasiatic elements in the Upper Cretaceous non-marine biotas of peninsular India. Cretaceous Research, 12: 177-183.

Sahni, A. \& Khosla, A. 1994. A Maastrichtian ostracode assemblage (Lameta Formation) from Jabalpur Cantonment, Madhya Pradesh, India. Current Science, 67(6): 456-460.

Sahni, B. \& Rode, K.P. 1937. Fossil plants from the intertrappean beds of Mohgaon-kalan in the Deccan, with a sketch of the Chhindwara district. Proceedings of the National Academy of Sciences of India, 7(3): $165-174$

Silva, M.D. 1978. Ostracodes da Formação Santana (Cretáceo Inferior) - Grupo Araripe nordeste do Brasil. 1 Novas espécie do gênero Bisulcocypris. Anais 30th Congreso Brasilero de Geologia, Recife, 2: 1023-1027.

Singh, S.D. 1995. Contributions to the palaeontology, biostratigraphy and palaeoecology of the Bombay and correlative intertrappeans of western India. Doctoral dissertation. Panjab University, Chandigarh, 1-176.

Singh, S.D. \& Sahni, A. 1996. Bombay Inter-trappeans: new data on age and faunal affinities. In: Pandey, J., Azmi, R.J., Bhandari, A. \& Dave, A. (Eds), Contributions to XV Indian Colloquium on Micropalaeontology and Stratigraphy, Dehra Dun. Geological Society of India, Bangalore, 465-469.

Sowerby, J. de C. 1840. On the fossils of the eastern portion of the Great Basaltic District of India. In: Malcolmson, J. C. (Ed.). Transactions of the Geological Society of London, 5: 532-575.

Srinivasan, S. 1996. Late Cretaceous eggshells from the Deccan Volcano-Sedimentary sequences of Central India. Memoir of the Geological Society of India., 37: 321-336.

Stankevitch, E.S. \& Sochava, A.V. 1974. Mongolian Senonian ostracods. Soviet-Mongolian Palaeontological Expedition, 1, Moscow, 268-286.

Szczechura, J. 1978. Fresh-water Ostracoda from the Upper Cretaceous of the Nemegt Basin, Gobi Desert. Palaeontologia Polonica, Warsaw, 21: $65-121$.

Szczechura, J. \& Blaszyk, J. 1970. Fresh-water Ostracoda from the Upper Cretaceous of the Nemegt Basin, Gobi Desert. In: Kielan-Jaworowska, Z. (Ed.), Results of the Polish-Mongolian Expeditions, Part 2. Palaeontologia Polonica, 21: 107-118. 
Udhoji, S.G. \& Mohabey, D.M. 1996. Ostracoda and Charophyta from the Late Cretaceous Lameta Formation of Maharashtra: Paleobiogeographic and age implication. In: Pandey, J., Azmi, R.J., Bhandari, A. \& Dave, A. (Eds), Contributions to XV Indian Colloquium on Micropalaeontology and Stratigraphy, Dehra Dun. Geological Society of India, Bangalore, 409-417.

Whatley, R.C. \& Bajpai, S. 2000a. A new fauna of Late Cretaceous non-marine Ostracoda from the Deccan Intertrappean beds of Lakshmipur Kachchh (Kutch) District, Gujarat, western India. Revista Española de Micropaléontologia, 32(3): 385-409.

Whatley, R.C. \& Bajpai, S. 2000b. Two additional ostracod species from the nonmarine intertrappean beds of Maastrichtian age in the Anjar region, Kachchh, Gujarat, western India. Revue de Micropaléontologie, 43(1-2): 173-178.

Whatley, R.C. \& Bajpai, S. 2000c. Zoogeographical relationships of the Upper Cretaceous nonmarine Ostracoda from the Deccan Traps, India. Current Research, 79(6): 694-696.

Whatley, R.C. \& Bajpai, S. In prep. The Upper Cretaceous nonmarine Ostracoda of the intertrappean beds of the Deccan Traps: new perspectives on their age, palaeoecology, zoogeography and evolution.

Whatley, R.C., Bajpai, S. \& Srinivasan, S. 2002. Upper Cretaceous nonmarine Ostracoda from intertrappean horizons in Gulbarga District, Karnataka State, South India. Revista Española de MicropaleontologÍa, 34: 163-186.
Whatley, R.C., Bajpai, S. \& Whittaker, J.E. In press a. Freshwater Ostracoda from the Upper Cretaceous intertrappean beds at Mamoni (Kota District), southeastern Rajasthan, India. Revista Española de Micropaleontologie.

Whatley, R.C., Bajpai, S. \& Whittaker, J.E. In press b. New records and new species of Upper Cretaceous non-marine intertrappean Ostracoda from Peninsular India. Bollettino della Societa Paleontologica Italiana.

Whatley, R.C., Bajpai, S. \& Whittaker, J.E. In press c. The identity of the non-marine ostracod Cypris subglobosa Sowerby from the Intertrappean deposits of Peninsular India. Palaeontology.

Whatley, R.C., Bajpai, S. \& Whittaker, J.E. In press d. Indian Intertrappean Ostracoda in the collections of the Natural History Museum, London. Cretaceous Research.

Yang, H-G., Cai, X. \& Su, W-H. 1989. On the characters of the of the ostracod assemblages of the Tiazhou Formation and the first member of the Funing Formation in northern Jiangsu and their geological age. (In Chinese with English abstract) Stratigraphy and palaeontology of the Taizhou Formation and the first member of the Funing Formation, North Jiangsu Basin. Nanjing University Press, Nanjing, 129-163.

Ye, C-H., Gou, Y-S., Hou, Y-T. \& Cao, M.Z. 1977. Mesozoic and Cenozoic Ostracoda fauna from Yunnan. In: Nanjing Institute of Geology and Palaeontology (Ed.), Mesozoic fossils of Yunnan, China, part 2. Science Press, Beijing, 153-330. 